\title{
An antagonist of retinoic acid receptors more effectively inhibits growth of human prostate cancer cells than normal prostate epithelium
}

\author{
RG Keedwell', Y Zhao', LA Hammond ${ }^{3}, K_{\text {Wen', S Qin }}^{2}$, LI Atangan², D-L Shurland², DMA Wallace ${ }^{4}$, R Bird', \\ A Reitmair ${ }^{2}$, RAS Chandraratna ${ }^{2,5}$ and G Brown*,I \\ 'Divisions of Immunity and Infection, University of Birmingham Medical School, Edgbaston, Birmingham BI 5 2TT, UK; ${ }^{2}$ Department of Biology, Allergan \\ Inc., Irvine, CA, USA; ${ }^{3}$ Divisions of Cancer Studies, University of Birmingham Medical School, Edgbaston, Birmingham BI5 2TT, UK; ${ }^{4}$ Department of \\ Urology, Queen Elizabeth Hospital, Birmingham BI5 2TH, USA; ${ }^{5}$ Retinoid Research, Department of Chemistry, Allergan Inc., Irvine, CA, USA
}

Screening of synthetic retinoids for activity against prostate carcinoma cell lines has identified antagonists of retinoic acid receptors (RARs) as potent growth inhibitors (Hammond et al, 200 I, Br J Cancer 85, 453-462). Here we report that 5 days of exposure to a high-affinity pan-RAR antagonist (AGN I943I0) abolished growth of prostate carcinoma cells from 14 out of I4 patients, with halfmaximal inhibition between 200 and $800 \mathrm{~nm}$. It had similar effects (at $\sim 250 \mathrm{~nm}$ ) on the prostate carcinoma lines LNCaP, DU- I 45 and PC-3. AGN 194310 inhibited the growth of normal prostate epithelium cells less potently, by $50 \%$ at $\sim$ I $\mu$. The growth of tumour cells was also inhibited more than that of normal cells when RAR $\beta$ together with RAR $\gamma$, but not RAR $\alpha$ alone, were antagonised. Treatment of LNCaP cells with AGN 194310 arrested them in GI of cell cycle within $12 \mathrm{~h}$, with an accompanying rise in the level of p2 I wafl. The cells underwent apoptosis within 3 days, as indicated by mitochondrial depolarisation, Annexin V binding and DNA fragmentation. Apoptosis was caspase-independent: caspases were neither cleaved nor activated, and DNA fragmentation was unaffected by the pan-caspase inhibitor Z-VAD-FMK. The ability of AGN 194310 to induce apoptosis of prostate cancer cells and its differential effect on malignant and normal prostate epithelial cells suggests that this compound may be useful in the treatment of prostate cancer.

British Journal of Cancer (2004) 91, 580-588. doi:I0.1038/sj.bjc.6602024 www.bjcancer.com

Published online 13 July 2004

(C) 2004 Cancer Research UK

Keywords: RAR antagonists; retinoic acid receptors; prostate cancer; growth inhibition; apoptosis

Retinoids are important modulators of the survival, growth, and differentiation of normal and malignant cells. Screening of synthetic analogues has identified compounds that display significant potential as preventive and therapeutic anticancer agents (reviewed in Altucci and Gronemeyer, 2001; Fontana and Rishi, 2002; Hammond et al, 2002; Ortiz et al, 2002; Sun and Lotan, 2002). In particular, compounds have been identified that provoke growth arrest and/or apoptosis in cells from malignant and common carcinomas for which new treatments are needed. These include prostate cancer, the most common noncutaneous male cancer (reviewed in Hammond et al, 2002). After androgen ablation therapy, prostate cancer typically progresses to late stage androgen-independent disease that is incurable (Kirby, 1996; Ismail and Gomella, 1997; Landis et al, 1998).

Recent enthusiasm for treating various malignancies with retinoids has been fuelled by the characterisation of a variety of synthetic retinoids with diverse modes of action. These retinoids fall into two main classes, termed classical and novel (Fontana and Rishi, 2002). 'Classical' retinoids bind to and activate (or inactivate) the retinoic acid receptors $(\operatorname{RAR} \alpha, \beta$ and $\gamma$ ) and

*Correspondence: Dr G Brown; Email: g.brown@bham.ac.uk

Received 22 December 2003; revised I June 2004; accepted 3 June 2004; published online 13 July 2004 retinoid X receptors $(\operatorname{RXR} \alpha, \beta$ and $\gamma)$. The 'novel' retinoids are synthetic retinoid-related molecules (RRMs) that exert at least some of their biological effects through RAR- and RXRindependent pathways (Fontana and Rishi, 2002; Ortiz et al, 2002). RRMs induce apoptosis in several types of malignant cells, including lung, cervical, breast and ovarian carcinomas and melanomas (Shao et al, 1995; Oridate et al, 1997; Piedrafita and Pfahl, 1997; Spanjaard et al, 1997; Sun et al, 1997; Li et al, 1998; Wu et al, 1998; Holmes et al, 2003).

ATRA and synthetic retinoid receptor agonists are not very effective in inducing growth arrest and/or apoptosis in prostate cancer cell lines such as LNCaP, DU-145 and PC-3: high concentrations $(\sim 1-10 \mu \mathrm{M})$ are generally needed (Gao et al, 1999; Hammond et al, 2001). When Lu et al (1999) screened more than 100 retinoids, three $\operatorname{RAR} \gamma$ agonists were the most active, but concentrations of $1-10 \mu \mathrm{m}$ were needed for complete growth inhibition. Similarly, we observed little effect of specific agonists of $\operatorname{RAR} \alpha$ and $\operatorname{RAR} \beta \gamma$ on colony formation by the above cell lines (Hammond et al, 2001). In clinical studies, 13-cis retinoic acid (isotretinoin) (with or without interferon- $\alpha$ ) is only modestly effective against prostate carcinoma (DiPaolo and Aisner, 1999; Kelly et al, 2000; Shalev et al, 2000).

By contrast, antagonists of $\operatorname{RAR} \alpha \beta \gamma$ and $\operatorname{RAR} \beta \gamma$ cause striking cell growth arrest and inhibition of colony formation in LNCaP, 
PC-3 and DU-145 cells. For example, the pan-antagonist AGN194310 inhibits colony formation at around $50 \mathrm{nM}-$ it is around 20 -fold more potent than ATRA, and promotes growth arrest and apoptosis (Hammond et al, 2001). AGN194310 also inhibited the growth of primary prostate carcinoma cells from two patients more effectively than ATRA (Hammond et al, 2001). That RAR antagonists suppress the growth of epithelial carcinomas more effectively than receptor agonists is also suggested by a report that the weak RAR antagonist MX718 inhibits the growth of breast carcinoma lines more potently than ATRA (Fanjul et al, 1998). Retinoid receptor antagonists may therefore have a potential for use in the treatment of human prostate and breast cancers.

We therefore compared the effects of the pan-RAR antagonist AGN194310 on primary cell cultures established from 14 patients with prostatic carcinoma and on normal prostate epithelial cells and fibroblasts. Its more potent effect on patients' prostate carcinoma cells than normal prostatic epithelium indicates that this agent may be useful in prostate cancer therapy.

\section{MATERIALS AND METHODS}

\section{Retinoids}

The pan-RAR antagonist (AGN194310), an RAR $\beta \gamma$ antagonist (AGN194431) and a specific RAR $\alpha$ antagonist (AGN196996), were synthesised at Allergan Inc. (Irvine, CA, USA). Their structures, receptor binding and transactivation properties have been described (Hammond et al, 2001). $K_{\mathrm{i}}$ values for binding of the antagonists to $\operatorname{RAR} \alpha, \beta$ and $\gamma$, respectively, are AGN194310: 3, 2 and 5 nM; AGN194431: 300, 6 and 20 nM; and AGN196996: 2, 1087 and $8523 \mathrm{~nm}$. These compounds show no activity in transactivation assays, but instead block the gene transcriptional activity induced by ATRA and other RAR agonists. To control for the detection of apoptosis and related events we used a RRM AGN193198 that induces apoptosis in a wide variety of cells through rapid caspase activation. AGN193198 does not bind to RARs and RXRs (Keedwell et al, 2004). Stock solutions were prepared at $10 \mathrm{~mm}$ in $50 \%$ ethanol $/ 50 \%$ dimethysulphoxide and stored at $-20^{\circ} \mathrm{C}$.

\section{Cell lines and cell culture}

Cultures of patients' carcinoma cells were established and maintained in serum-free medium and, for comparison, the cell lines investigated were grown serum-free or in low serum. Serumfree grown sublines of the prostate carcinoma cell lines LNCaP, PC-3 and DU-145 (serum stocks from ATCC, Rockville, MD, USA) have been described previously (Hammond et al, 2001). These lines were grown in RPMI 1640 medium (Gibco-BRL, Paisley, UK) containing antibiotics $\left(100 \mathrm{U} \mathrm{ml}^{-1}\right.$ penicillin and $100 \mu \mathrm{g} \mathrm{ml}^{-1}$ streptomycin) and supplemented with insulin, transferrin, selenium dioxide, linoleic acid and bovine serum albumin ITS $^{+}$, Sigma, Poole, UK). The breast carcinoma lines MDA-MB-231 and MCF-7 (provided by Dr K Colston, St Georges Hospital, London) were adapted to growth in serum-free medium (MDA-MB-231) and in RPMI 1640 medium supplemented with $0.5 \%$ foetal bovine serum and antibiotics (Gibco-BRL, MCF-7) as described before (see Hammond et al, 2001). A subline of the promyeloid cell line HL60 has been grown long-term in serum-free $\left(\right.$ ITS $\left.^{+}\right)$medium (Bunce et al, 1995). Cells were grown at $37^{\circ} \mathrm{C}$ in a humidified atmosphere of $5 \% \mathrm{CO}_{2}$ in air, and adherent cells were passaged by trypsinising with trypsin-EDTA (Gibco-BRL).

\section{Growth of primary cell cultures}

Core biopsies were obtained from patients undergoing investigation for suspected prostatic carcinoma. Consent for the use of this material for research was obtained from the South Birmingham
Local Research Ethics Committee of the Birmingham Health Authority. Informed consent was also obtained from the patients. Histological reports were obtained from the Department of Pathology, The Medical School, University of Birmingham, and confirmed that the biopsies contained adenocarcinoma. Slides and cases were also reviewed by one of the investigators (LAH).

Cultures were established as described by Peehl et al (1991), using the serum-free medium Prostate Epithelial Cell Growth Medium (PrEGM) supplemented with SingleQuots (BioWhittaker, Wokingham, UK). The biopsies were collected in ice-cold Hanks's buffered salt solution (HBSS) without phenol red (Gibco-BRL). Biopsies were washed $3 \times$ with HBSS, and cut into very small $\left(<1 \mathrm{~mm}^{3}\right)$ pieces using a sterile scalpel blade. Cultures were established by placing the pieces of tissue into a $25 \mathrm{~cm}^{2}$ collagen 1coated flask (Greiner, Stonehouse, UK) containing $1 \mathrm{ml}$ of complete PrEGM medium. The time from collection to setting up the cultures was $\sim 3 \mathrm{~h}$. By day 4 , the pieces of tissue had attached to the flask, and $4 \mathrm{ml}$ of PrEGM were added. Cells were subcultured at $80-95 \%$ confluence by using trypsin/EDTA, which was inactivated by adding a 10 -fold greater volume of complete PrEGM. Cells were pelleted by centrifugation, and set in fresh collagen-1-coated flasks. Plates coated with collagen 1 (Greiner, Stonehouse, UK), and PrEGM were used for assays.

A primary culture of normal prostate epithelium cells (PrEC) was purchased from Cambrex Bio Science (Wokingham, UK). These cells test positive for cytokeratin (clone 8.13). The culture has a doubling time of $18-24 \mathrm{~h}$, and undergoes $\sim 15$ population doublings. Normal prostate fibroblasts grew out rapidly from a prostate biopsy that was nonmalignant, and the established culture consisted entirely of spindled fibroblast cells. The normal prostate epithelial cells and fibroblasts were grown as above.

\section{Analysis of the effects of antagonists on cell growth}

Trypsinised cell suspensions were plated into a 96-well microtitre plate at 400 cells per well in $100 \mu \mathrm{l}$ of ITS $^{+}$medium (cell lines) or PrEGM (primary cells). Typically, these cells grow exponentially with doubling times between 20 and $24 \mathrm{~h}$. Cells were treated, in triplicate, with retinoids immediately and at day 2 by replacing the medium. The number of viable cells was assessed at day 5 by measuring cellular ATP levels using the Vialight HS High Sensitivity Cell Proliferation/Cytotoxicity Kit according to the manufacturer's instructions (Lumi Tech, Nottingham, UK), using a Berthold LB953 luminometer. Vehicle alone had no effect on any of the cells tested.

Cell cycle status was measured by staining harvested cells with propidium iodide (PI, Molecular Probes, Eugene, OR, USA) in buffer $\left(10 \mu \mathrm{g} \mathrm{ml}^{-1}\right.$ PI in $1 \%\left(\mathrm{w} \mathrm{v}^{-1}\right)$ tri-sodium citrate, $0.1 \%\left(\mathrm{vv}^{-1}\right)$ Triton X100, $100 \mu \mathrm{M} \mathrm{NaCl}$ ). The distribution of cells between phases of the cell cycle was determined using a Becton-Dickinson Flow Cytometer and CellFIT Cell-Cycle Analysis software.

\section{Measurements of apoptotic events}

Bulk cultures of LNCaP cells and primary prostate carcinoma cells were seeded at $5 \times 10^{5}$ cells per $75 \mathrm{~cm}^{2}$ flask and AGN194310 was added immediately. Cells in suspension and adherent cells, harvested by trypsinisation, were pooled and apoptotic cells were identified by the TUNEL assay (Gorczyca et al, 1993). An FITCconjugated antibody to bromodeoxyuridine (Becton-Dickinson \& Co., Mountain View, CA, USA) was used to identify cells labelled with bromodeoxyurindine triphosphate and fluorescence was measured by FACS analysis at $510-550 \mathrm{~nm}$.

Changes to the mitochondrial membrane potential after treatment of bulk cultures of cells with AGN194310 were measured by incubating harvested cells with $5 \mu \mathrm{g} \mathrm{ml}^{-1}$ of the fluorescent probe JC-1 $\left(5,5^{\prime}, 6,6^{\prime}\right.$-tetrachloro-1, $1^{\prime}, 3,3^{\prime}$-tetrabenzimidazolylcarbocyanine iodide, Eastman Kodak Co., Rochester, NY, USA) for 
$20 \mathrm{~min}$ at $37^{\circ} \mathrm{C}$ in an atmosphere of $5 \% \mathrm{CO}_{2}$. After washing twice in phosphate-buffered saline for $10 \mathrm{~min}$, cells were analysed on a Becton-Dickinson FACS (Salvioli et al, 1997).

Binding of Annexin V was determined as follows. LNCaP cells were plated onto 24 -well plates (6000 cells per well) in medium containing $1 \mu \mathrm{M}$ AGN194310 or the equivalent amount of vehicle, and they were cultured for 1, 2 or 3 days. After careful removal of the medium, $200 \mu \mathrm{l}$ of buffer $(1 \times \mathrm{PBS}, 5 \mathrm{~mm} \mathrm{CaCl}, 140 \mathrm{~mm} \mathrm{NaCl})$ containing $3 \mu \mathrm{g} \mathrm{ml}^{-1}$ Annexin V (Roche, Indianapolis, IN, USA) and $20 \mu \mathrm{g} \mathrm{ml}^{-1}$ PI were added to each well and incubated in the dark for $15 \mathrm{~min}$. Fluorescent microscopy was performed using an Axiovert 100 fluorescent microscope (Zeiss, Jena, Germany) with Image-Pro 4.5 software (Media Cybernetics, Silver Spring, MD, USA) for image capture and overlay.

For Fluorescence-Activated Cell Sorter (FACS) analysis of the levels of apoptosis, LNCaP cells were plated onto $60 \mathrm{~mm}$ dishes $\left(1 \times 10^{5}\right.$ cells per dish) and treated with $0.1,0.5$, or $1 \mu \mathrm{M}$ AGN194310. Apoptosis was evaluated by Annexin-V-FITC/PI double staining using the Apoptosis Detection Kit (Oncogene, San Diego, CA, USA), according to the manufacturer's instructions. Flow cytometry was performed with a FACS Calibur (Becton Dickinson, Sunnyvale, USA), and Cell Quest Pro software. Single stain controls were performed for each analysis.

\section{Caspase studies}

The pan-caspase inhibitor Z-VAD-FMK (R\&D Systems, Abingdon, UK) was used to investigate the involvement of caspases in AGN194310-induced apoptosis. A $20 \mathrm{~mm}$ stock solution was prepared in dimethysulphoxide. Z-VAD-FMK was added at $50 \mu \mathrm{M}$ to bulk cultures of cells $1 \mathrm{~h}$ before adding AGN194310, and cells were monitored using the TUNEL assay.

Fluorometric assays for caspase activity were conducted in 96well microtitre plates. In total, $50 \mu \mathrm{l}$ of assay buffer ( 20 mM HEPES, $\mathrm{pH} 7.5,10 \%$ glycerol, $2 \mathrm{~mm}$ dithiothreitol) containing $50 \mu \mathrm{M}$ of peptide substrates for caspase-3 (DEVD-AFC), caspase-8 (IETDAFC), or caspase-9 (LEHD-AFC) (all from Biovision Inc. Mountain View, CA, USA) were added to each well. In total, $50 \mu \mathrm{l}$ of cell lysate were added to initiate the reactions. Backgrounds were measured in wells that contained assay buffer, substrate and lysis buffer. Fluorescence was measured on a CytoFlour 4000 fluorescence plate reader (Applied Biosystems) set at $400 \mathrm{~nm}$ excitation and $508 \mathrm{~nm}$ emission. Caspase activities were calculated as fold increases relative to control wells.

Antibodies to caspase-3 (Stressgen), caspase-8 (Cell Signalling Technology) and caspase- 9 (Cell Signalling Technology) were used to stain blots to detect cleaved (active) forms of these enzymes. Cells $\left(1 \times 10^{7} \mathrm{ml}^{-1}\right)$ were lysed in ice-cold buffer $(5 \mathrm{~mm}$ EDTA, $150 \mathrm{~mm} \mathrm{NaCl}, 1 \%$ Triton X-100, $100 \mu \mathrm{M} \mathrm{Na} \mathrm{NO}_{4}, 2 \mathrm{~mm}$ phenylmethylsulphonyl fluoride, $10 \mu \mathrm{g} \mathrm{ml}^{-1}$ leupeptin, $50 \mathrm{~mm}$ Tris, $\mathrm{pH}$ 7.4) for $30 \mathrm{~min}$ with gentle rotation at $4^{\circ} \mathrm{C}$. Lysates were clarified by centrifugation at $16000 \times g$ for $15 \mathrm{~min}$ at $4^{\circ} \mathrm{C}$, resolved on SDS PAGE, and transferred onto PVDF membranes for immunostaining. Immunoreactive proteins were visualised by enhanced chemiluminescence.

\section{Immunodetection of $\mathrm{p} 21^{\text {waf1 }}$ and $\mathrm{p} 27^{\mathrm{kip} 1}$}

Blots of cell lysates were stained with antibodies to p21 waf1 (sc-397,

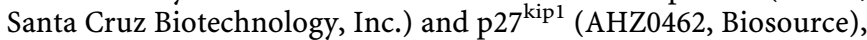
and immunoreactive proteins were visualised by enhanced chemiluminescence.

\section{Data manipulation and statistical analyses}

At least three experiments of each type were performed with triplicate replicates. Results are expressed as means \pm standard errors of means (s.e.m.). The statistical significance between groups of data was analysed by the Student's $t$-test using the SigmaStat $^{\mathrm{TM}}$ (version 8.0) statistical software package. Doseresponse curves for compounds were plotted using the kinetics module of the Sigmaplot ${ }^{\mathrm{TM}}$ (version 8.0) graphics software package.

\section{RESULTS}

\section{The pan-RAR antagonist AGN194310 is a potent growth inhibitor of prostate carcinoma cells}

Core biopsies of prostate tissue were obtained from patients attending a diagnostic urological clinic and in whom there was a high clinical suspicion of prostatic carcinoma. Following histological examination of the cores and reporting of invasive carcinoma, the patients received androgen ablation (cyprotone acetate and zolodex). All of the patients responded to therapy as revealed by substantial reductions in their serum levels of prostatespecific antigen (PSA, see Figure 1).

Epithelial carcinoma cells were grown from the above core biopsies of 14 patients with prostatic carcinoma. The biopsies

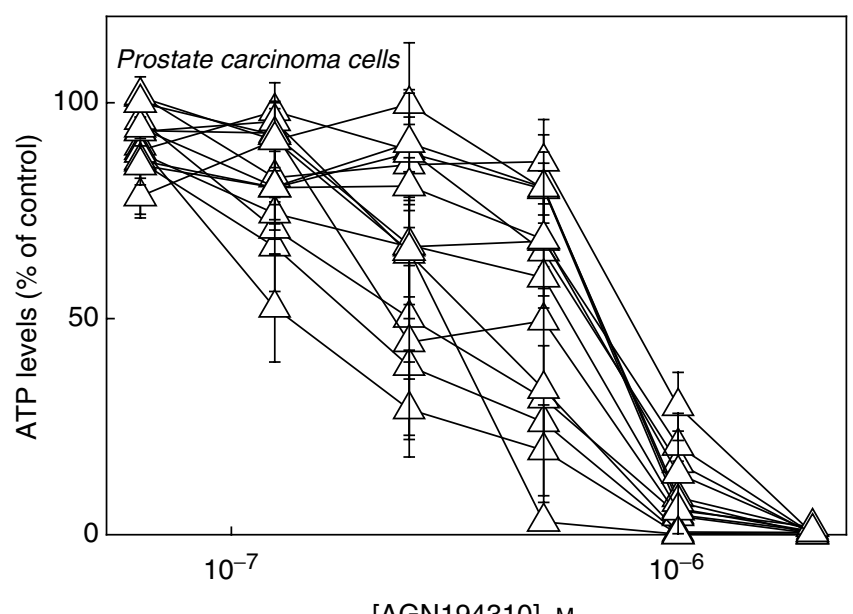

[AGN194310], M

\begin{tabular}{|c|c|ccc|c|}
\hline Patient & $\begin{array}{c}\text { Gleason } \\
\text { grading }\end{array}$ & \multicolumn{2}{|c|}{$\begin{array}{c}\text { Serum PSA } \\
\text { pre } \rightarrow \text { post-therapy }\end{array}$} & $\begin{array}{c}\text { IC }_{50}, \mathrm{nM} \\
\text { AGN194310 }\end{array}$ \\
\hline PrC1 & 9 & 60.6 & $\rightarrow$ & 2.78 & $800 \pm 223$ \\
\hline PrC2 & 9 & 12 & $\rightarrow$ & 0.02 & $576 \pm 36$ \\
\hline PrC3 & 7 & 97.5 & $\rightarrow$ & 0.25 & $461 \pm 88$ \\
\hline PrC5 & 9 & 452 & $\rightarrow$ & 42 & $836 \pm 48$ \\
\hline PrC7 & 5 & 59 & $\rightarrow$ & 14 & $561 \pm 96$ \\
\hline PrC8 & 8 & 108 & $\rightarrow$ & 1.33 & $240 \pm 32$ \\
\hline PrC9 & 10 & 434 & $\rightarrow$ & 9.6 & $283 \pm 56$ \\
\hline PrC10 & 8 & 154 & $\rightarrow$ & 2.16 & $634 \pm 136$ \\
\hline PrC11 & 9 & 76 & $\rightarrow$ & 2.0 & $459 \pm 56$ \\
\hline PrC12 & 9 & 45 & $\rightarrow$ & 0.47 & $569 \pm 138$ \\
\hline PrC13 & 7 & 36 & $\rightarrow$ & 2.17 & $246 \pm 25$ \\
\hline PrC15 & 7 & 28 & $\rightarrow$ & 3.4 & $208 \pm 60$ \\
\hline PrC16 & 9 & 49 & $\rightarrow$ & 6.1 & $299 \pm 70$ \\
\hline PrC17 & 9 & 57 & $\rightarrow$ & 12.4 & $339 \pm 19$ \\
\hline
\end{tabular}

Figure I AGNI943I0 potently inhibits the growth of patients' prostate carcinoma cells. Activity of AGN 194310 against carcinoma cells from core biopsies of 14 patients with prostatic carcinoma was measured by seeding cells into wells of a microtitre plate, treating with agent immediately and at day 2 , and measuring cellular ATP levels at day 5 . The top panel shows the titration curves obtained for each of the patients' cells. The $I C_{50}$ values shown in the table are means \pm s.e. of data obtained from three separate experiments. 
contained extensive carcinoma, and cells in the cultures established were almost entirely polygonal, epithelial cells. The cells expressed prostate-specific antigen, as revealed by immunocytochemical staining. Their epithelial nature was confirmed by positive immunocytochemical staining for cytokeratin. Cultures contained few fibroblasts and stromal (smooth muscle) cells, as revealed by immunostaining for cytokeratin and smooth muscle actin.

Cells from each of 14 patients were tested, at passage 2, for sensitivity to AGN194310 and ATRA. In the microtitre plate assay, AGN194310 completely inhibited growth at 1-2 $\mu \mathrm{M}$. There was some variability in the sensitivity of individual patients' cells to AGN194310, with concentrations that reduced cell numbers by $50 \%$ ( IC $_{50}$ values) ranging from $\sim 200$ to $\sim 800 \mathrm{~nm}$ (Figure 1 ). $\mathrm{IC}_{50}$ values were not related to Gleason grading or to pre- and posttherapy PSA levels (see Figure 1). ATRA (up to $2 \mu \mathrm{M}$ ) had little effect on cells from 13 patients, and an $\mathrm{IC}_{50}$ value of $1 \mu \mathrm{M}$ was obtained for cells from patient PrC2 (data not shown).

\section{AGN194310 inhibits the growth of human prostate cancer cells more potently than normal prostate epithelium}

We compared the activities of AGN194310 against three prostate carcinoma lines, a patient's primary carcinoma cells and normal prostate-derived epithelial cells and fibroblasts. Prostatic fibroblasts were grown from a nonmalignant biopsy: the culture contained no epithelial cells.

Figure 2A shows the data from parallel studies of AGN194310 activity against LNCaP, PC-3 and DU-145 cells, against epithelial primary cultures from a patient with prostate carcinoma, and against normal prostate epithelium cells. AGN194310 potently reduced cell numbers when the three prostate carcinoma cell lines were grown in microtitre wells, with $\mathrm{IC}_{50}$ values of $343 \pm 78 \mathrm{nM}$ for LNCaP cells, $183 \pm 76 \mathrm{nM}$ for PC- 3 cells and $243 \pm 56 \mathrm{~nm}$ for DU-145 cells. In total, $500 \mathrm{~nm}$ AGN194310 reduced cell numbers by $\sim 80 \%$ in the cultures of the three prostate carcinoma lines and the patient's primary cells, and it had no effect on the normal prostate epithelium cells. The prostate carcinoma cell lines were approximately four times as sensitive to AGN194310 as normal prostate epithelial cells $(P=0.004)$, and comparison of the $\mathrm{IC}_{50}$ value for normal cells $v$ s individual values for LNCaP, PC-3 and DU-145 cells gave $P$-values of $0.008,0.001$ and 0.009 , respectively. Moreover, the dose-response curve for the normal prostate epithelium cells was displaced to the right of the dose-response curves for the carcinoma cells from all of the 14 patients' carcinoma cells (compare Figures 1 and 2). The normal prostate fibroblasts $\left(\mathrm{IC}_{50}\right.$ $\sim 0.8 \mu \mathrm{M}$ ), like the normal prostate epithelial cells $\left(\mathrm{IC}_{50} \sim 1 \mu \mathrm{M}\right.$, $P=0.4$ for comparison of these two $\mathrm{IC}_{50}$ values), were less sensitive to AGN194310 than the prostate carcinoma cells.

To compare the involvement of the three RARs in controlling the growth and survival of malignant and normal cells, antagonists of RAR $\beta \gamma$ (AGN194431) and of RAR $\alpha$ (AGN196996) were also titrated against $\mathrm{LNCaP}$ and normal prostate epithelial cells (Figure 2B and C). As reported previously (Hammond et al, 2001), the $\operatorname{RAR} \beta \gamma$ antagonist was as potent as the pan-antagonist against LNCaP cells $\left(\mathrm{IC}_{50}=291 \pm 76 \mathrm{nM}\right)$, and the $\mathrm{RAR} \alpha$ antagonist $\left(\mathrm{IC}_{50}=1.8 \pm 0.3 \mu \mathrm{M}\right.$ ) was less potent (compare Figures $2 \mathrm{~A}, \mathrm{~B}$ and C). The $\operatorname{RAR} \beta \gamma$ antagonist was more active against LNCaP cells than against the normal prostate epithelium cells $(P=0.1$ for comparison of $\mathrm{IC}_{50}$ values), but this differential effect was less than for the pan-specific antagonist AGN194310. The RAR $\alpha$ antagonist did not discriminate between LNCaP cells and normal prostate epithelial cells ( $P=0.4$ for comparison of $\mathrm{IC}_{50}$ values).

\section{AGN194310 provokes growth arrest in G1}

Previously we reported that AGN194310 induces growth arrest and apoptosis of LNCaP cells (Hammond et al, 2001). Here we report
A
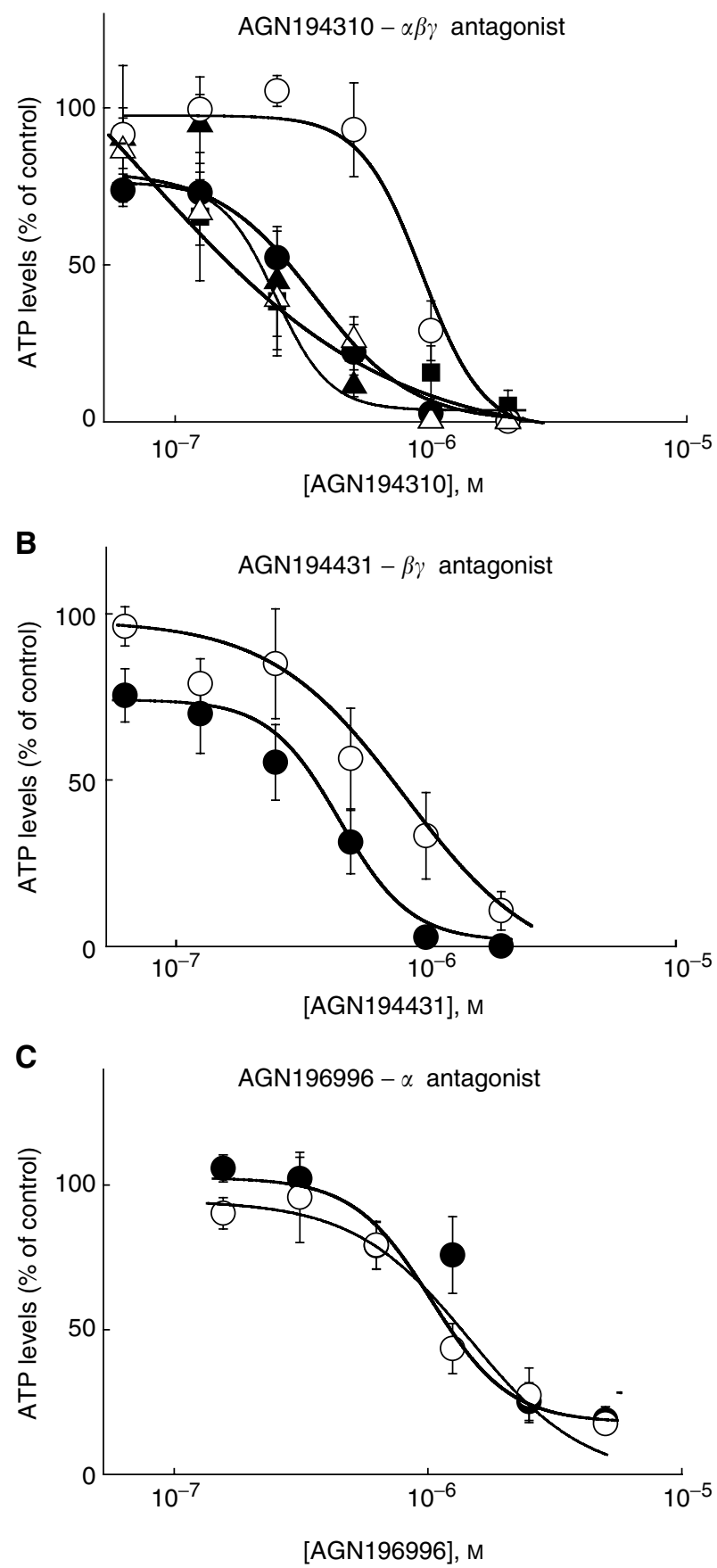

Figure 2 Pan-RAR antagonist AGNI94310 affects the growth of prostate carcinoma cells more than that of normal prostate epithelium. The top panel shows the activity of the pan-RAR antagonist AGN I943I0 against LNCaP cells (closed circles), PC-3 cells (closed triangles), DU- I45 (squares) a patient's primary carcinoma cells (open triangles) and normal prostate epithelium (open circles). The lower panels show the activities of antagonists of RAR $\beta \gamma$ (AGNI9443I) and RAR $\alpha$ (AGN 196996) against LNCaP cells (closed circles) and normal prostate epithelium (open circles). Activities were measured by seeding cells into wells of a microtitre plate, treating with agents immediately and at day 2 , and measuring cellular ATP levels at day 5. Data are means \pm s.e. of values obtained from six $(\mathbf{A})$, four $(\mathbf{B})$ and three $(\mathbf{C})$ experiments. The $P$-values obtained when the $I C_{50}$ value for AGN 194310 against normal prostate epithelium was compared with $I C_{50}$ values against LNCaP, PC-3 and DU- $\mid 45$ cells are $0.008,0.00 \mid$ and 0.009 , respectively. Comparison of the $I_{50}$ values for $A G N I 9443 I$ against normal prostate epithelium and LNCaP cells gave a $P$-value of 0.1 , and a $P$-value of 0.4 was obtained for this comparison for AGNI96996. 
detailed kinetics of these processes. Treatment of LNCaP cells with $1 \mu \mathrm{M}$ AGN194310 first led to a substantial increase in the proportion of cells in G1 of cell cycle, which reached a maximum level that was maintained from $\sim 12 \mathrm{~h}$ (see Figure $3 \mathrm{~A}$ ), with a corresponding decline in the population of $S$ phase cells.

$\mathrm{P} 21^{\text {waf1 }}$ was detected at low levels in LNCaP cells, and AGN194310 $(1 \mu \mathrm{M})$ provoked an increased expression from $\sim 12 \mathrm{~h}$ onwards (Figure 4 ). The accumulation of $\mathrm{p} 21^{\text {wafl }}$ occurred at about the same time as cells accumulated in G1 of cell cycle. $\mathrm{P} 27^{\mathrm{kip} 1}$ was not detectable in untreated LNCaP cells, and was present at a very low level even after treating for $48 \mathrm{~h}$ with AGN194310. The detectability of induced expression of $\mathrm{p} 27^{\mathrm{kip} 1}$ was controlled by observing a large rise (at $48 \mathrm{~h}$ ) upon treatment of LNCaP cells with AGN193198. This compound also induced a very rapid and substantial rise in the level of expression of $\mathrm{p} 21^{\text {waf1 }}$.

\section{Apoptosis follows G1 arrest}

Levels of apoptosis were monitored by following changes in the mitochondrial potential, by the appearance of phosphatidylserine at the cell surface, and by detection of DNA-strand breaks (Figures
3B and 5). Apoptosis was induced progressively in AGN194310treated cells $-50 \%$ of the cells had depolarised mitochondria by $40-50 \mathrm{~h}$, and cells displaying DNA-strand breaks accumulated progressively after $\sim 40 \mathrm{~h}$. After 3 days, $\sim 70 \%$ of cells showed mitochondrial depolarisation, DNA strand-breaks were detected in $\sim 50 \%$ of cells, and $60 \%$ of the cells had exposed phosphatidylserine at their cell surface and so bound Annexin V (Figure 5).

\section{AGN194310-induced apoptosis in LNCaP cells is caspase- independent}

To investigate the role of caspases in AGN194310-induced apoptosis, LNCaP cells were treated for $1 \mathrm{~h}$ with the pan-caspase inhibitor Z-VAD-FMK $(50 \mu \mathrm{M})$ prior to adding $1 \mu \mathrm{M}$ AGN194310. The inhibitor only slightly reduced the proportion of cells showing DNA strand-breaks at day 3 (Figure $3, P$-value 0.01 ). The Z-VADFMK used was biologically active. The RRM AGN193198 potently induces apoptosis in a variety of cells, and $\sim 80 \%$ of treated LNCaP cells showed mitochondrial depolarisation and DNA fragmentation by day 3. Z-VAD-FMK $(50 \mu \mathrm{M})$ largely prevented this apoptosis (15\% apoptotic cells, $P$-value 0.004 , Figure $3 B$ ).

\section{A}

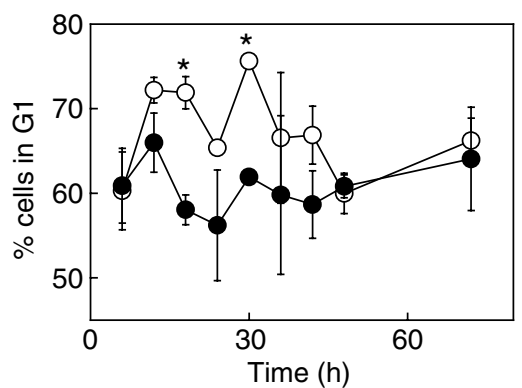

Control, 30 h, $58 \%$ G1, $28 \%$ S
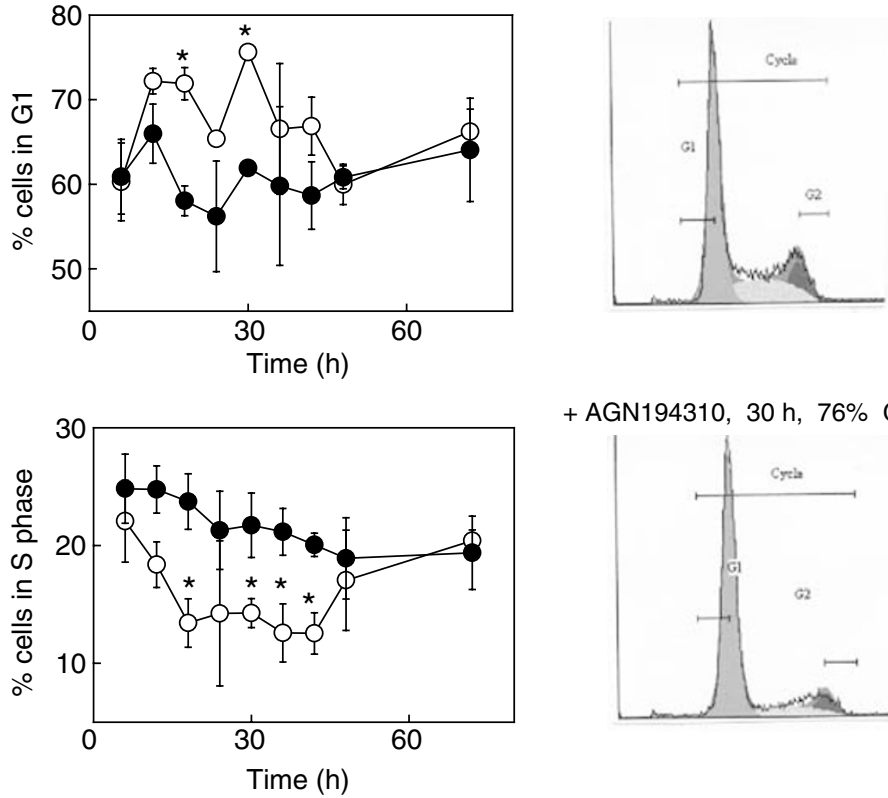

+ AGN194310, $30 \mathrm{~h}, 76 \%$ G1, 15\% S
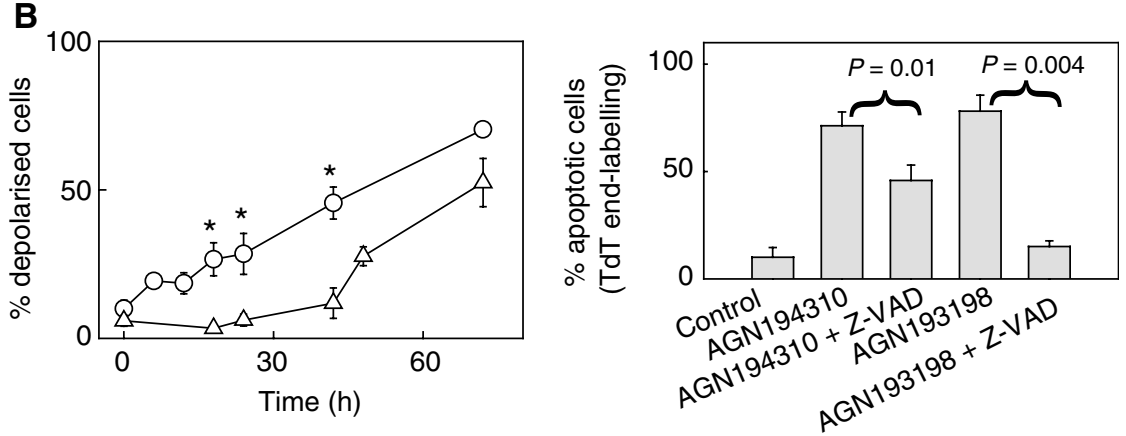

Figure 3 AGNI943IO causes LNCaP cells to arrest in GI and later undergo apoptosis. (A) Kinetics of changes to the cell cycle status of LNCaP cells treated with I $\mu$ M AGNI943IO (open circles) as compared to the status of control (untreated) cultures (closed circles). Cell cycle status was measured after staining cells with propidium iodide, and representative profiles are shown. (B) Time course for the induction of mitochondrial membrane depolarisation (open circles) and the appearance of DNA-strand breaks (TUNEL assay, open triangles) when LNCaP cells were treated with I $\mu \mathrm{M}$ AGNI943I0. The right panel shows that AGN 1943 I 0 -induction of DNA-strand breaks was largely unaffected by treating LNCaP cells with the pan-caspase inhibitor (at $50 \mu \mathrm{M}$ ) for I h before adding I $\mu$ M AGN 1943 I 0 for 3 days. By contrast, Z-VAD-FMK blocked AGN I 93 I 98-induced apoptosis. Data are means \pm s.e. of values obtained from three time course experiments, and five experiments using the pan-caspase inhibitor. *Denotes $P$-values $<0.05$. 

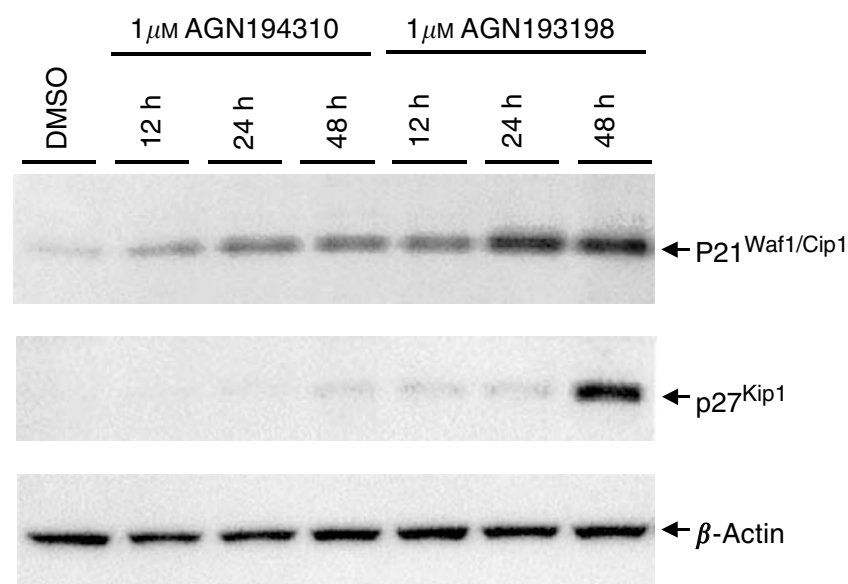

Figure 4 AGNI943I0 increases $p 2 I^{\text {wafl }}$ protein levels in LNCaP cells. Blots of cell extracts were immunostained with antibodies to $\left.p 2\right|^{\text {wafl }}$ and $p 27^{\mathrm{kip}}$. The figure shows that $\mathrm{p} 21$, but not $\mathrm{p} 27$, increased in level when LNCaP cells were treated with AGN I943IO. To control for the detection of p27, LNCaP cells were treated with the RRM AGN I93198.

Caspases-3, -8 and -9 were not cleaved or activated when LNCaP cells were treated with $1 \mu \mathrm{M}$ AGN194310 (Figure 6). Enzyme activities remained unchanged, and immunostaining of cell extracts did not detect cleaved forms. In parallel control experiments, $6 \mathrm{~h}$ of treatment of Jurkat $\mathrm{T}$ cells with $4 \mu \mathrm{M}$ AGN193198 induced 25-, four- and eight-fold increases in the activities of caspases-3, -8 and -9 (Figure 6A, lower panel), and cleaved forms of these enzymes were readily detectable by $4 \mathrm{~h}$ (Figure 6B, right panel).

\section{HL60 leukaemia and breast carcinoma cells are less sensitive to AGN194310 than prostate cancer cells}

Table 1 compares the $\mathrm{IC}_{50}$ values obtained from titrations of AGN194310 against prostate carcinoma cells and other cell types that we tested. AGN194310 does not inhibit colony formation by single HL60 cells plated in microtitre plate wells (Hammond et al, 2001). When AGN194310 was screened for activity against HL60 cells plated in microtitre wells, an $\mathrm{IC}_{50}$ value of $1.3 \mu \mathrm{M}$ was obtained (data not shown). The breast carcinoma lines MCF-7 and MDAMB-231 were less sensitive than the prostate carcinoma lines to growth inhibition by AGN194310. A 50\% inhibition of growth was not achieved for MCF-7 cells at $2 \mu \mathrm{M}$ AGN194310, and an $\mathrm{IC}_{50}$ value of $\sim 800 \mathrm{~nm}$ was obtained for MDA-MB-231 cells.

\section{DISCUSSION}

Finding new treatments for malignant carcinomas requires the identification of new agents that potently induce growth arrest and/or apoptosis, and that are more effective against malignant

Figure 5 LNCaP cells undergoing AGN I943I0-induced apoptosis bind Annexin V. LNCaP cells were treated with I $\mu \mathrm{M}$ AGN 943 I0, or vehicle control (DMSO) and stained with Annexin $\vee$ and propidium iodide. Fluorescence microscopy at day $3(\mathbf{A})$ reveals early apoptotic cells (Annexin $\mathrm{V}+$ ve; green), as well as late apoptotic/necrotic cells (Annexin V + ve/propidium iodide + ve; yellow-red) in AGN 1943 I0-treated cultures. (B) Representative FACS cytograms of stained cells. Viable cells (Annexin $\checkmark$ and propidium iodide $-v e$ ) are in the lower left-hand quadrant. Early apoptotic cells (Annexin $V+$ ve/propidium iodide -ve) are in the lower right-hand quadrant. Terminal apoptotic/necrotic cells (Annexin $V+$ ve/ propidium iodide + ve) are in the upper right-hand quadrant. (C) Results of the flow cytometry analyses are summarised. Data are means \pm s.e. of values from at least three experiments. **Denotes $P$-values $<0.001$. cells than normal cells. For example, the synthetic retinoid CD437 induces rapid apoptosis in human lung cancer cell lines but not in two types of normal lung epithelial cells (Sun et al, 2002), and it also induces apoptosis in malignant human epidermal keratinocytes but not in normal keratinocytes (Hail and Lotan, 2001).

Here, we have shown that the pan-specific RAR antagonist AGN194310 potently inhibits the growth of prostate carcinoma

A

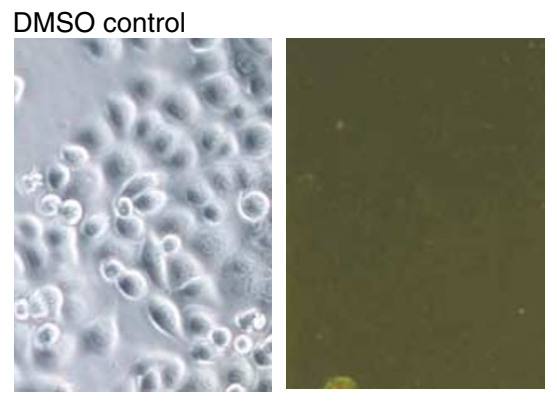

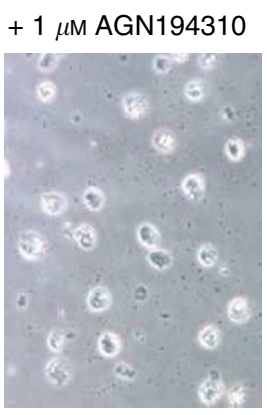

Bright field

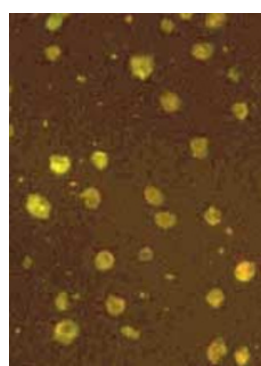

Fluorescence
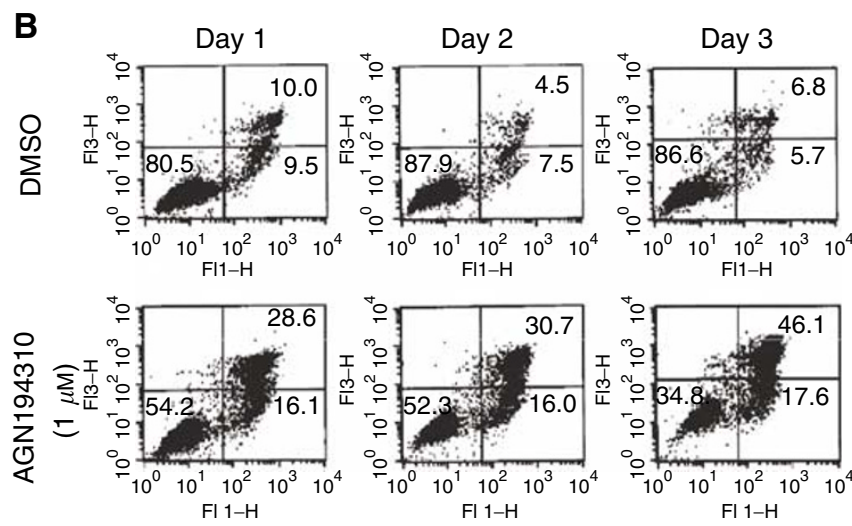

C

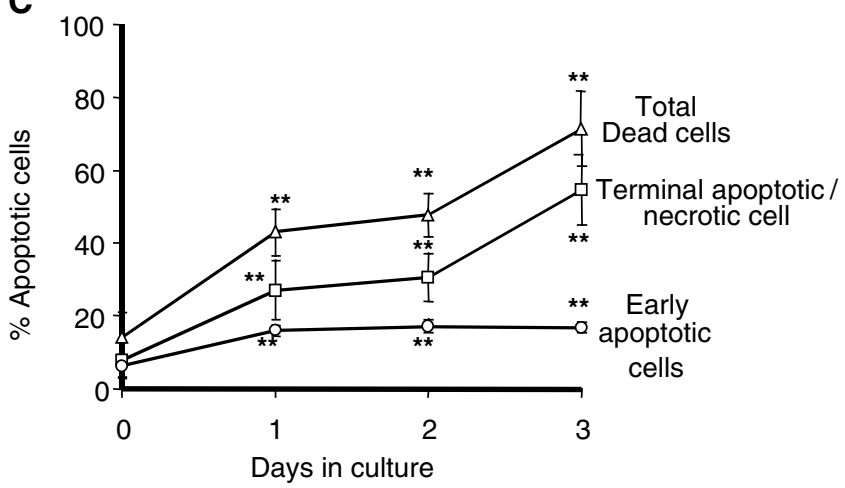


A
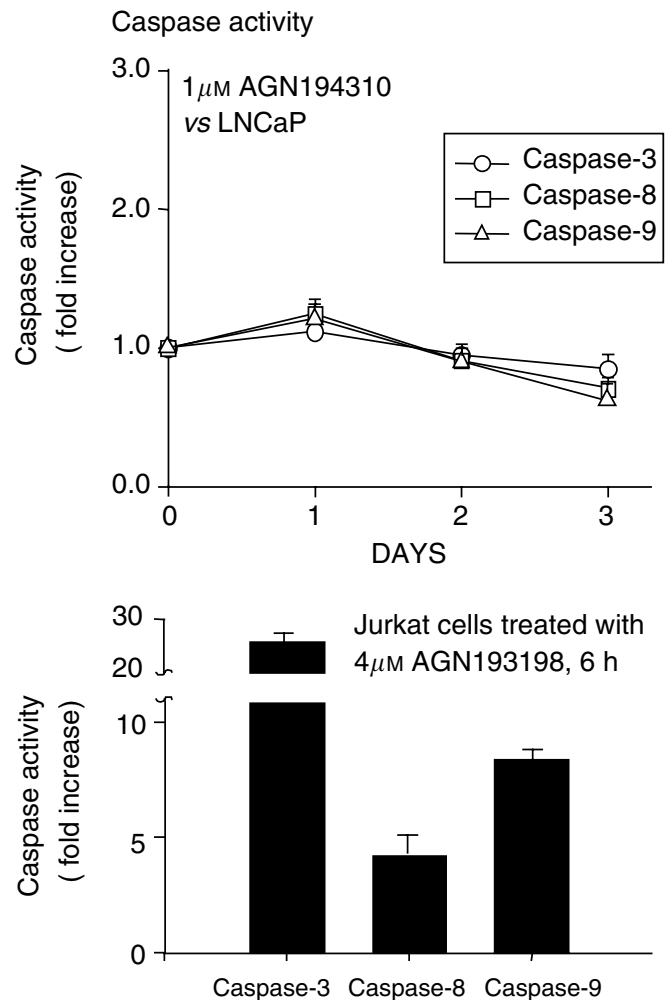

B Caspase cleavage

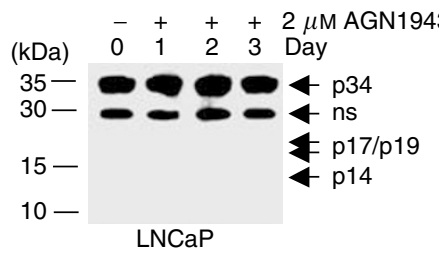

IB: anticaspase - 3

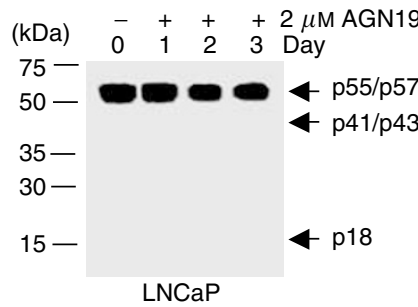

IB: anticaspase - 8
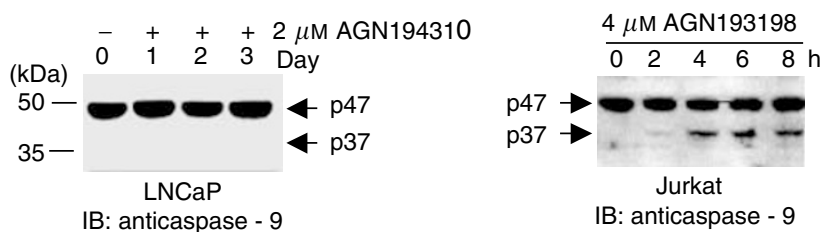

Figure 6 Caspases are neither cleaved nor activated in AGNI94310treated LNCaP cells. (A) that caspases-3, -8 and -9 were not activated in LNCaP cells treated with I $\mu \mathrm{M}$ AGN 194310. To control for detection of activated enzymes, Jurkat $T$ cells were treated for $6 \mathrm{~h}$ with $4 \mu \mathrm{M}$ AGNI93198 (bottom panel). Enzyme activities were measured using peptide substrates. (B) Caspases-3, -8 and -9 were not cleaved in AGNI943I0 (I $\mu \mathrm{M}$ )-treated LNCaP cells, as revealed by immunostaining blots of cell extracts. To control for detection of cleaved (active) forms of caspases, Jurkat $\mathrm{T}$ cells were treated with $4 \mu \mathrm{M}$ AGNI93198 (right immunoblots).
Table I Growth inhibitory activity of the pan-RAR antagonist AGNI94310 against various cell types

\begin{tabular}{lc}
\hline Cells & IC $_{\mathbf{5 0}}$ of $\mathbf{A G N} \mathbf{~ 9 4 3 ~ I 0 ~ ( n M ) ~}$ \\
\hline Prostate carcinoma cells & \\
Patients' primary cells & $208 \pm 60$ to $836 \pm 48$ \\
LNCaP & $343 \pm 78$ \\
PC-3 & $183 \pm 76$ \\
DU-I45 & $243 \pm 56$ \\
& \\
Other malignant cells & \\
MCF-7 (breast carcinoma) & $>2000$ \\
MDA-MB-2I3 (breast carcinoma) & $781 \pm 27$ \\
HL60 (promyeloid leukaemia) & $1338 \pm 318$ \\
& \\
Normal prostate cells & $960 \pm 134$ \\
Epithelium & $786 \pm 12$ \\
Fibroblasts &
\end{tabular}

$I C_{50}$ values were determined using the microtitre plate assay, and are means \pm s.e. of values obtained from at least three separate experiments.

cells, which display an accumulation of $\mathrm{p} 21^{\text {waf1 }}$, are arrested in G1 of cell cycle, and then undergo apoptosis. Similarly, the RAR antagonist BMS453 causes accumulation of $\mathrm{p} 21^{\text {wafl } 1}$ and G1 arrest of normal breast cells (Yang et al, 2001). The antiproliferative effects of several agents against prostate carcinoma cell lines have been attributed to upregulation of p $21^{\text {wafl }}$ expression: for example, $\mathrm{G} 1$ accumulation of $\mathrm{LNCaP}$ in response to $1 \alpha, 25$-dihydroxyvitamin $\mathrm{D}_{3}$ (Moffat et al, 2001; Yang et al, 2002). Prostate carcinoma cell lines that do not undergo growth arrest in response $1 \alpha, 25$ dihydroxyvitamin $\mathrm{D}_{3}$ fail to upregulate p $21^{\text {wafl }}$ (Moffat et al, 2001). Other agents that induce G1 arrest of prostate carcinoma lines, such as 12-O-tetra-decanoylphorbol-13-acetate, indole-3-carbinol and inositol hexaphosphate, also upregulate p2 $1^{\text {waf1 }}$ and p2 $7^{\text {Kip } 1}$, leading to decreases in cyclin-dependent kinase activities (Chinni et al, 2001; Sugibayashi et al, 2002; Singh et al, 2003).

The pan-specific RAR antagonist AGN194310 largely prevented the growth in microtitre wells of malignant prostate epithelium cells from androgen-responsive patients and of LNCaP, PC-3 and DU-145 cells at submicromolar concentrations. Previously, we have reported that this compound reduces viable cell numbers in flask cultures of LNCaP cells and of patients' prostatic carcinoma cells (Hammond et al, 2001). Also, AGN194310 potently inhibits colony formation by LNCaP ( $\mathrm{IC}_{50} 16 \mathrm{nM}$ ), PC-3 (IC $\left.\mathrm{IC}_{50} 18 \mathrm{nM}\right)$ and DU-145 ( $\mathrm{IC}_{50} 34 \mathrm{~nm}$ ) cells (Hammond et al, 2001). That more AGN194310 is required to reduce cell numbers in microtitre wells is commensurate with the view that the colony formation assay is the more sensitive. Normal prostate epithelial cells were substantially less sensitive to AGN194310 than carcinoma cells. This compound may, therefore, have potential for killing tumour cells in vivo while sparing normal cells. Relative insensitivity of normal prostate fibroblasts, haemopoietic cells such as HL60, and breast carcinoma cells to AGN194310 (Hammond et al, 2001) also indicate that other cell types might be spared in vivo.

Several observations suggest that AGN194310 induces G1 arrest of prostate carcinoma cells through a mechanism that involves antagonism of multiple RARs, rather than some unrelated target molecule(s). The pan-specific RAR antagonist AGN194310 and the $\operatorname{RAR} \beta \gamma$ antagonist AGN194431 have different structures, but both inhibit colony formation by and growth in liquid culture of prostate carcinoma cells at low concentrations. It seems unlikely that these two compounds could both bind with similar high affinities to a second target. Moreover, the pan-RAR agonist TTNPB ((E)-4-[2-(5,6,7,8-tetrahydro-5,5,8,8-tetramethyl-2-naphthalenyl-1propenyl]-benzoic acid) overcomes the growth inhibitory effect of AGN194310 (Hammond et al, 2001). It seems likely that 
AGN194310 abolishes RAR-mediated effects of agonistic retinoids that facilitate the proliferation of prostate carcinoma cells. These RAR-mediated effects must be achieved by a very low level of retinoid signalling that is caused by trace amounts of retinoids that the cells encounter while grown serum-free - very small amounts of retinoids may contaminate the medium constituents. Alternatively, the growth inhibitory effects of AGN 194310 may result from direct pharmacological effects involving assembly of RAR complexes containing corepresser molecules.

Previously, we argued that $\operatorname{RAR} \gamma$ antagonism may be sufficient to compromise the growth of LNCaP, PC-3 and DU-145 cells that are grown long-term serum-free, since these cells express only RAR $\alpha$ and RAR $\gamma$ (Campbell et al, 1998; Hammond et al, 2001; and data not shown), and $\operatorname{RAR} \beta \gamma$ antagonism is as effective as panantagonism. The importance of RAR $\gamma$ in maintaining growth and/ or survival of prostate epithelium is supported by findings from RAR $\gamma$-null mice, the prostates of which show atrophy and squamous metaplasia (Lohnes et al, 1993). The RAR $\alpha$-null mouse does not show these defects (Lufkin et al, 1993). However, we cannot exclude the biological involvement of a very low level of $\operatorname{RAR} \beta$ expression in the human cell lines and tumours. $\operatorname{RAR} \beta$ was not detected by immunoblotting cell extracts, but a band is just visible on immunoblots of extracts of serum-grown LNCaP cells that are known to express RAR $\beta$ (Campbell et al, 1998; Hammond et al, 2001). Many studies have suggested a role for $\operatorname{RAR} \beta$ in modulating the growth and survival of prostate cancer cells (reviewed in Zhang, 2002). For example, stable expression of RAR $\beta$ in $\operatorname{RAR} \beta$-negative PC-3 cells increases their sensitivity to growth inhibition by agonistic retinoids (Campbell et al, 1998). In the present study, the difference in sensitivity of the malignant and normal cells to the RAR $\beta \gamma$ antagonist was less than when RAR signalling was extinguished by the $\operatorname{RAR} \alpha \beta \gamma$ antagonist. That gene expression regulated by $\operatorname{RAR} \gamma$ or $\operatorname{RAR} \beta$ might be more necessary to the growth of prostate carcinoma cells than their normal counterparts remains an interesting possibility.

Paradoxically, agonists and antagonists of RARs both provoke growth arrest of prostate carcinoma cells (Lu et al, 1999; Hammond et al, 2001). But, assuming that serum free-grown LNCaP, PC- 3 and DU-145 cells express $\alpha$ and $\gamma$, we do not know how the various gene regulatory activities of these two receptors contribute to promoting and/or arresting the growth of cells. ATRA provokes G1 arrest and differentiation of HL60 cells

\section{REFERENCES}

Altucci L, Gronemeyer H (2001) The promise of retinoids to fight against cancer. Nat Rev Cancer 1: 181-193

Brietman TR, Selonick SE, Collins SJ (1980) Induction of differentiation of the human promyelocytic cell line (HL60) by retinoic acid. Proc Natl Acad Sci USA 77: 2936-2940

Bunce CM, Wallington LA, Harrison P, Williams GR, Brown G (1995) Treatment of HL60 cells with various combinations of retinoids and $1 \alpha$, 25 dihydroxyvitamin $\mathrm{D}_{3}$ results in differentiation towards neutrophils or monocytes or a failure to differentiate and apoptosis. Leukaemia 9: $410-418$

Campbell MJ, Park S, Uskokovic MR, Dawson MI, Koeffler HP (1998) Expression of the retinoic acid receptor- $\beta$ sensitises prostate cancer cells to growth inhibition mediated by combinations of retinoids and 19-nor hexafluoride vitamin $\mathrm{D}_{3}$. Endocrinology 139: 1972 - 1979

Chinni SR, Upadhyay S, Koppolu PK, Sarkar FH (2001) Indole-3-carbinol (I3C) induced growth inhibition, G1 cell cycle arrest and apoptosis in prostate cancer cells. Oncogene 20: 2927-2936

Ding W, Li YP, Noble LM, Grills G, Carrera I, Paietta E, Tallman MS, Wiernik PH, Gallagher RE (1998) Leukaemia cellular retinoic acid resistance and missense mutations in the PML-RAR $\alpha$ fusion gene after relapse of acute promyelocytic leukaemia from treatment with all-trans retinoic acid and intensive chemotherapy. Blood 92: $1172-1183$
(Brietman et al, 1980) via RAR $\alpha$ : this is the major receptor expressed in undifferentiated myeloid cells (Zhu et al, 2001), and resistance of myeloid cells to ATRA is related to dominantnegative RAR $\alpha$ mutations (Ding et al, 1998; Duprez et al, 2000). One possible explanation of the growth inhibitory activities of both agonists and antagonists against prostate carcinoma cells is that agonism of RAR $\alpha$ drives gene expression leading to cell growth arrest, but also that antagonism of $\operatorname{RAR} \gamma$ switches off expression of a molecule(s) that plays a role in facilitating cell proliferation. The relative contributions of positive and negative effects on cell growth may determine the final outcome.

Prostate carcinoma cells that growth-arrested in response to AGN194310 quickly underwent apoptosis. Most studies of apoptosis focus on caspases as critical elements: the steps leading to DNA fragmentation are generally considered to be caspase-3 initiated (Enari et al, 1999). Caspases have also been proposed as the major effectors of the action of RRMs (You et al, 2001; LopezHernandez et al, 2003). However, the pan-caspase inhibitor ZVAD-FMK did not substantially affect the induction of apoptosis by AGN194310, and caspases-3, -8 and -9 were neither cleaved nor activated. Hence, we conclude that AGN194310-provoked apoptosis is caspase-independent.

There is other evidence that caspases are not essential for apoptosis, nor is caspase activity sufficient to execute cell death (Lukovic et al, 2003). Endonuclease G is an apoptotic DNAase that is released from the mitochondria ( $\mathrm{Li}$ et al, 2001), and etoposideinduced apoptosis in the HeLa cells involves caspase-independent activation of endonucleases (Torriglia et al, 1999). Indeed, triggering of caspase-independent cell death has been proposed as a means of combating cancer (reviewed in Sun et al, 2000; Mathiasen and Jaattela, 2002; Lewis et al, 2003).

Our studies suggest that AGN194310 may be useful in the treatment of prostate cancer, and this compound is under clinical development.

\section{ACKNOWLEDGEMENTS}

This work was supported by a grant from Allergan Inc. Irvine, CA. We are grateful to Robert Michell, Ron Lai, Karyn Siemasko and Peter Baciu for their valuable comments.
DiPaolo RS, Aisner J (1999) Overcoming bcl-2 and p53-mediated resistance in prostate cancer. Semin Oncol 26: $112-116$

Duprez E, Benoit G, Flexor M, Lillehaug JR, Lanotte M (2000) A mutated $\mathrm{PML} / \mathrm{RAR} \alpha$ found in the retinoid maturation resistant NB4 subclone, NB4-R2, blocks $\operatorname{RAR} \alpha$ and wild type PML/RAR $\alpha$ transcriptional activities. Leukaemia 14: 255-261

Enari M, Sakahira H, Yakoyama H, Okawa K, Iwamatsu A, Nagata SA (1999) Caspase activated DNAase that degrades DNA during apoptosis and its inhibitor ICAD. Nature 391: 43-50

Fanjul AN, Piedrafita FJ, Al-Shamma H, Pfahl M (1998) Apoptosis induction and potent antiestrogen receptor-negative breast cancer activity in vivo by a retinoid antagonist. Cancer Res 58: $4607-4610$

Fontana JA, Rishi AK (2002) Classical and novel retinoids: their targets in cancer therapy. Leukaemia 16: 463-472

Gao M, Ossowski L, Ferrari AC (1999) Activation of Rb and decline in androgen receptor protein precede retinoic acid induced apoptosis in androgen-dependent LNCaP cells and their androgen-independent derivative. J Cell Physiol 179: 336-346

Gorczyca W, Bigman K, Mittleman A, Ahmed T, Gong J, Melamed MR, Darzynkiewicz Z (1993) Induction of DNA strand breaks associated with apoptosis during treatment of leukaemias. Leukaemia 7: $659-670$ 
Hail N, Lotan R (2001) Sythetic retinoid CD437 promotes rapid apoptosis in malignant human epidermal keratinocytes and G1 arrest in their normal counterparts. J Cell Physiol 188: $98-105$

Hammond LA, Brown G, Keedwell RG, Durham J, Chandraratna RAS (2002) The prospects of retinoids in the treatment of prostate cancer. Anti-Cancer Drugs 13: 781 - 790

Hammond LA, Van Krinks CH, Durham J, Tomkins SE, Burnett RD, Jones EL, Chandraratna RAS, Brown G (2001) Antagonists of retinoic acid receptors (RARs) are potent growth inhibitors of prostate carcinoma cells. Br J Cancer 85: $453-462$

Holmes WF, Soprano DR, Soprano KJ (2003) Comparison of the mechanism of induction of paoptosis in ovarian carcinoma cells by the conformationally restricted synthetic retinoids CD437 and 4-HPR. J Cell Biochem 89: $262-278$

Ismail M, Gomella LG (1997) Current treatment of advanced prostate cancer. Techs Urol 3: 16-24

Keedwell RG, Zhao Y, Hammond LA, Qin S, Tsang K-Y, Reitmair A, Molina Y, Okawa Y, Atangan LI, Shurland D-L, Wen K, Wallace DMA, Bird R, Chandraratna RAS, Brown G (2004) A retinoid-related molecule that does not bind to classical retinoid receptors potently induces apoptosis in human prostate cancer cells through rapid caspase activation. Cancer Res 64: $3302-3312$

Kelly KW, Osman I, Reuter VE, Curley T, Heston WD, Nanus DM, Scher HI (2000) The development of biological end points in patients treated with differentiation agents: an experience of retinoids in prostate cancer. Clin Cancer Res 6: $834-846$

Kirby RS (1996) Recent advances in the medical management of prostate cancer. Br J Clin Pract 50: 88-93

Landis SH, Murray T, Bolden S, Wingo PA (1998) Cancer Statistics, 1998. CA Cancer J Clin 48: 6-29

Lewis AE, Wong BCY, Langman MJS, Eggo MC (2003) Protein kinase C inhibition induces DNA fragmentation in COLO 205 cells which is blocked by cysteine protease inhibition but not mediated through caspase 3. Exp Cell Res 289: $1-10$

Li LY, Luo X, Wang X (2001) Endonuclease G is an apoptotic DNAase when released from mitochondria. Nature 412: $95-99$

Li Y, Lin B, Agadir A, Dawson MI, Reed JC, Fontana JA, Bost F, Hobbs PD, Zheng Y, Chen GQ, Shroot B, Mercola D, Zhang XK (1998) Molecular determinants of AHPN (CD437)-induced growth arrest and apoptosis in human lung cancer cell lines. Mol Cell Biol 18: 4719-4731

Lohnes D, Kastner P, Dierich A, Mark M, LeMeur M, Chambon P (1993) Function of retinoic acid receptor $\gamma$ in the mouse. Cell 73: 643-658

Lopez-Hernandez FJ, Ortiz MA, Bayon Y, Piedrafita FJ (2003) Z-FA-fmk inhibits effector caspases but not initiator capsases 8 and 10, and demonstrates that novel anticancer retinoid-related molecules induce apoptosis by the intrinsic pathway. Mol Cancer Ther 2: 255-263

Lu X-P, Fanjul A, Picard N, Shroot B, Pfahl M (1999) A selective retinoid with high activity against an androgen-resistant prostate cancer cell type. Int J Cancer 80: 272-278

Lufkin T, Lohnes D, Mark M, Dierich A, Gorry P, Gaub M-P, LeMeur M, Chambon P (1993) High postnatal lethality and testis degeneration in retinoic acid receptor $\alpha$ mutant mice. PNAS USA 90: 7225-7229

Lukovic D, Komoriya A, Packard BZ, Ucker DS (2003) Caspase activity is not sufficient to execute cell death. Exp Cell Res 289: 384-395

Mathiasen IS, Jaattela M (2002) Triggering caspase-independent cell death to combat cancer. Trends Mol Med 8: 212-220

Moffat KA, Johannes WU, Hedlund TE, Miller GJ (2001) Growth inhibitory effects of 1alpha, 25-dihydroxyvitamin $\mathrm{D}(3)$ are mediated by increased levels of p21 in the prostatic carcinoma cell line ALVA-31. Cancer Res 61: $7122-7129$

Oridate N, Higuchi M, Suzuki S, Shroot B, Hong WK, Lotan R (1997) Rapid induction of apoptosis in human C33A cervical carcinoma cells by the synthetic retinoid 6-[3-(1-adamantly) hydroxyphenyl]-2-naphtalene carboxylic acid (CD437). Int J Cancer 70: 484-487

Ortiz MA, Bayon Y, Lopez-Hernandez FJ, Piedrafita FJ (2002) Retinoids in combination therapies for the treatment of cancer: mechanisms and perspectives. Drug Resitance Updates 5: 162-175
Peehl DM, Wong ST, Terris MK, Stamey TA (1991) Culture of prostate epithelial cells from ultrasound-guided needle biopsies. Prostate 19: $141-147$

Piedrafita FJ, Pfahl M (1997) Retinoid-induced apoptosis and Sp1 cleavage occur independently of transcription and require caspase activation. Mol Cell Biol 17: 6348-6358

Salvioli S, Ardizzoni A., Franceschi C, Cossarizza A (1997) JC-1, but not $\mathrm{DIC}_{6}(3)$ or rhodamine 123 , is a reliable fluorescent probe to assess $\Delta \Psi$ changes in intact cells: implications for studies on mitochondrial functionality during apoptosis. FEBS Lett 411: 77-82

Shalev M, Thompson TC, Frolov A, Lippman SM, Hong WK, Fritsche H, Kadmon D (2000) Effect of 13-cis-retionic acid on serum prostatespecific antigen levels in patients with recurrent prostate cancer after radical prostatectomy. Clin Cancer Res 6: 3845-3849

Shao Z-M, Dawson MI, Li X-S, Rishi AK, Sheikh MS, Han QX, Ordonez JV, Shroot B, Fontana JA (1995) P53 independent G1/G0 arrest and apoptosis induced by a novel retinoid in human breast cancer cells. Oncogene 11: $493-504$

Singh RP, Agarwal C, Agarwal R (2003) Inositol hexaphosphate inhibits growth, and induces G1 arrest and apoptotic death of prostate carcinoma DU145 cells: modulation of CDKI-CDK-cyclin and pRb-related proteinE2F complexes. Carcinogenesis 24: 555-563

Spanjaard RK, Ikeda M, Lee PJ, Charpentier B, Chin WW, Eberlien TJ (1997) Specific activation of retinoic acid receptors (RARs) and retinoid $\mathrm{X}$ receptors reveals a unique role for RARgamma in induction of differentiation and apoptosis of S91 melanoma cells. J Biol Chem 272: $18990-18999$

Sugibayashi R, Kiguchi Y, Shimizu T, Suzuki T, Hamada H, Takeda K (2002) Up-regualtion of p21 (WAF1/CIP1) levels leads to growth suppression of prostate cancer cell lines. Anticancer Res 22: 713-719

Sun S-Y, Lotan R (2002) Retinoids and their receptors in cancer development and chemoprevention. Crit Rev Oncol/Hematol 41: $41-45$

Sun S-Y, Yue P, Lotan R (2000) Implication of multiple mechanisms in apoptosis induced by the synthetic retinoid CD437 in human prostate carcinoma cells. Oncogene 19: 4513-4522

Sun S-Y, Yue P, Chen X, Hong WK, Lotan R (2002) The synthetic retinoid CD437 selectively induces apoptosis in human lung cancer cells while sparing normal human lung epithelial cells. Cancer Res 62: $2430-2436$

Sun S-Y, Yue P, Shroot B, Hong WK, Lotan R (1997) Induction of apoptosis in human non-small cell lung carcinoma cells by a novel synthetic retinoid CD437. J Cell Physiol 173: 279-284

Torriglia A, Negri C, Chaudun E, Prospri E, Courtois Y, Counis MF, Scovassi A (1999) I Differential involvement of DNAases in HeLa cell apoptosis induced by etoposide and long term-culture. Cell Death Differ 6: $234-244$

Wu S, Zhang D, Donigan A, Dawson MI, Soprano DR, Soprano KJ (1998) Effects of conformationally restricted synthetic retinoids on ovarian tumor cell growth. J Cell Biochem 68: 378-388

Yang ES, Maiorino CA, Roos BA, Knight SR, Burnstein KL (2002) Vitamin D-mediated growth inhibition of an androgen-ablated LNCaP cell line model of human prostate cancer. Mol Cell Endocrinol 186: $69-79$

Yang L, Ostrowski J, Reczek P, Brown P (2001) The retinoic acid receptor antagonist, BMS453, inhibits normal breast cell growth by inducing active TGF $\beta$ and causing cycle arrest. Oncogene 20: $8025-8035$

You KR, Shin MN, Park RK, Lee SO, Kim DG (2001) Activation of caspase-8 during $N$-(4-hydroxyphenyl) retinamide-induced apoptosis in Fasdefective hepatoma cells. Hepatology 34: 1119-1127

Zhang X-Y (2002) Vitamin A and apoptosis in prostate cancer. EndocrineRelat Cancer 9: 87-102

Zhu J, Heyworth CM, Glasgow A, Huang Q-H, Petrie K, Lanotte M, Benoit G, Gallagher R, Waxman S, Enver T, Zelent A (2001) Lineage restriction of $\operatorname{RAR} \alpha$ gene expression in myeloid differentiation. Blood 98: $2563-2567$ 